was exhibited in a travelling show. Attached to the neck is a mandible with teeth and tongue; an orifice associated with the tongue led into the cow's pharyux. A study of this and similar recorded examples leadis me to endorse Gurlt's opinion, that these cervical tecth, mandible, and tongue arie reminants of an accessory head and the fistula represents the mouth of the rudimentary head. The inuseum contains some admirable examples of bicephalous skulls of calves. These double skulls are remarkable from the constancy with which they are conjoined in the mastoid region. A useful specimen shows a well-formed skull, with one less perfectly developed, firmly fused to it in the mastoid region (Fig. 11).

'The critical stindy of a laige number of such skulls leaves no escape from the conclusion that mastoid teeth and an auricular sinus in horses, like a cervical ostium and teeth in a sheep or an ox, are remnants of an accessory or parasitic head. Mastoid teeth are memorials of a lost individual.

T'eeth are conspicuous and easily recognized. They develop and calcify during fetal life into resisting structures and serve as useful signs. This is illustrated by a monstrous pig I dissected and added to the Teratological Gallery in 1888. "The pig in external appearance is double in all parts except the head and neck. I made a complete examination of the head and found a pair of fused maxillae impacted between the normal jaws, and felt convinced that an accessory mandible existed somewhere about the pig's head. At last I found a rudimentary parasitic mandible, with teeth hanging like a polypus in the pharynx, and attached by a narrow pedicle to the base of the skull. It is the oddest example of a misplaced organ that has come under my notice.

If Professor Keith accepts my explanation of the origin of mastoid teeth, he will realize that they are misplaced in the Dental Collection. Their proper place in this museum is the Teratological Gallery.

\section{THE MICROSCOPIC EXAMINATION OF}

\section{THE BRAINS OF TWO MEN DEAD OF COMMOTIO} CEREBRI (SHELL SHOCK) WITHOUT VISIBLE EXTERNAL INJURY.*

\section{[With Special Plate.]}

$B \mathbf{Y}$

F. W. MOTT, M.D., LL.D., F.R.S., F.R.C.P.,

PATHOLOGIST TO THE LONDON COUNTY COONCIL ASYLCMS, MAODSLEY HOSPIFAL, DENMARK HILL.

The examination of the brains of two cases of death from shell shock without visible injury and without punctate haemorrhages indicative of gas poisoning is of interest for several reasons. So far as I know, it is the first description that has been given which serves to explain (1) sudden death in shell shock, and (2) the clinical symptoms which persist for some time after the commotion of the brain in non-fatal cases.

I am indebted to Lieut.-Colonel T. R. Elliott and Professor Arthur Keith for sending me the brains, and to the officers whose names are mentioned for the clinical notes and the notes of the post-mortem examination.

\section{CASE I.}

Clinical Notes.

In this case the man developed, according to a notefurnisher by Captain J. London, a degree of nervousuess on the Somme which lie never lost, but was able to control for" six months. Later he was in an area which was subjected to an intense bom bardment, during which, as far as can be ascertained, no gas shells were used. This lasted about four hour's (February 22nd, 4 p.m. to 8 p.m.). Although he remarked to another man that he "could not stand it much longer," he did not give way until the following day, twelve hours later, when perhaps six shells came over (February 23rd, 8 a.m.).

He was not buried nor gassed. One shell burst just behind his dug-out-namely, $10 \mathrm{ft}$. away-in the moruing, but many must have been as near the previuus day. Early symptoms were tremors and general depression. The later symptom (February 22nd) - were coarse tremors of the limbs, crying (February 23rd), inability to walk or do anything. He would not answer questions-very like the-hysterical manifestations of melancholia. The pupils were dilated. Captein London'states

* The expenses connected with this investigation were defrayed cut of a Governmentetarit of the Board of Cojitrol. that he was rather busy with some wounded at the time, and did not make a detailed examination.

A note by Captain Francis A. Duffield, R.A.M.C.(S.R.), states that the man was admitted to the field ambulance in the evening in a state of acute mania, shouting "Keep them back, keep them back." He was quite uncontrollable and quite impossible to examine. He was quieted with morphine and chloroform, and got better and slept well all night. In a later̂. note Lieut.-Colonel J. F. Crombie, in command of the field ambulance, stated that the patient had at least two hypodermic injections of morphine while in the ambulance. Next moluing he woke up apparently well, and suddenly died.

\section{Necropsy.}

- The following is a report by Captain A. Stokes; R.A.M.C. (Mobile Laboratory); on the post-mortem examination, made on he afternoon of the day of death:

There were no marks of external violence on the body other In some small scratches on the anterior chest wall.

Thorax.-The lungs were oedematous, and in the substance of the lower lobe of the left lung there was a considerable haemorrhage. The right luing, except for oedema, was normal.

Heart.-Enlarged, and the right side dilated. The muscle was good, and there was no valvular lesion.

Abdominal Cavity.-Normal. There was no pathological cliange in the stomach, oesophagus, intestine, or great intestine. The liver was normal in size, and was somewhat cons gested. The spleen was normal. The kidneys were small, but showed no gross change. "The urine contained neither sugar nor albumin.

Skull. - There was a slight bruise on the scalp, in the frontal region. The brain was extremely congested, and on each side of every superficial vessel there was an ecchymosis. There were a number of minute punctiform haemorrhages at the terminations of the smallest vessels on the surface of the brain. The whole brain was soft but not markedly oedematous. The cerebro-spinal fluid appeared to be blood-tinged. There was considerable ecchymosis on each side of the great sinuses of the skull. There was no large haemorrhage found, and no small intracerebral petechiae. There was no gross lesion of tho viscera, which would have been a cause of death; but though
I have never seen a post-mortem examination on a man who has clied of "shell shock," I consider the condition of the brain is consistent with that diagnosis.

Mrcroscopic Examination of the Brain of Case I.

The brain had been preserved in Kaiserling's fluid, and it was not in very good condition, but seeing that it was placed in this fluid less than twelve hour's after death, it is probable that the portions examined yielded satisfactory material for microscopic investigation.

The portions of brain selected were prepared for section by the paraffin method of serial sections. The dyes used to stain the sections were as follows: (1) Haematoxylin and eosin, (2) Van Gieson, (3) thionin, (4) polychrome and eosin. The sections were $5 \mu$ in thickness and were mounted, after staining, in Canada balsam.

Cerebrum: Top of Ascending Frontal Convolution-Leg Area.-The veins are congested both in the meninges and in the substance of the grey and white matter. There is subpial haemorrhage here and there owing to rupture of the dilated congested veins. There are no punctate haemorrhages observable. The perivascular spaces of the arterioles, capillaries, and venules are dilated, also the perineuronal spaces are distinctly seen, some being apparently connected with the perivascular spaces. In some of the sections empty collapsed vessels can be discerned. in places. The general appearance suggests deficiency of blood in the arteries and capillaries, with engorgement of the venous system. $A$ condition very similar to that observed in experimental anaemia in animals produced by ligation of both carotids and vertebrals. There is some degree of chromatolysis of the cells. The Betz cells are the easiest, on account of their size, to recognize this change, and Fig. 1 shows the early chromatolysis of these psychomotor neurones.

The pole of the first frontal shows marked congestion of the vessels and some subpial haemorrhage from dilated congested reins. Many of the arterioles and capillaries are empty and collapsed, and there is the same appearance of dilatation of the perivascular sheaths and perineuronal spaces. The pyramidal cells also show early chromatolytic changes.

Internal Capsule.-There is general congestion of roins, and the small vessels appear to be either empty and collapsed, or contain less blood than nornial. Some of the vessels show haemorrhage into the sheath. (Fig. 3.)

Corpus Callosim.-The small vessels are congested and dilated, some liave ruptured into the slieath, other small vessels have ruptured into the tissue. There are no typical punctate haèmorrhages such as are secn in gas 
poisoning, which are due to hyaline thrombosis of terminal arterioles.

Pons.-There is a marked congestion of veins and some of the smaller veins have ruptured, giving rise to haemorrhage into the sheath; blood corpuscles are also seen extravasated in the adjacent nervous tissue. 'There are small haemorrhages in the white matter (Fig. 3). There is dilatation of the perivascular sheaths and perineuronal spaces together with collapsed and empty vessels or partially empty vessels. The haemorrhages, here as elsewhere, appear to be of recent occurrence. Nearly all the cells show some degree of early chromatolytic change.

Medulla.-Sections only of the medulla at the point of the calamus scriptorius were made, as the upper part of the medulla was rather damaged. In the anterior median fissure a vessel had ruptured, and there were free corpuscles in the leptomeninges. . All the veins on the surface of the medulla were congested. In serial sections the ruptured vessel entering the anterior median fissure and penetrating the median raiphe could be followed, and here it was seen to have ruptured into the perivascular space (Fig. 4), and blood corpuscles are seen extravasated into the-adjacent tissue. The perivascular and perineuronal spaces are seen dilated both in the medulla and pons (Fig. 7). The cells of the medulla show early chromatolytic changes as a rule. The cells of the vago-accessorius nucleus (Fig. 5) show much more chromatolysis than the adjacent cells of the $h$ moglossal nucleus (Fig. 6). These nuclei are distant about $2 \mathrm{~mm}$. from the ruptured rossel in the median raphe.

Cerebellum.-Sections stained with thionin and safranin show very unequal staining of the Purkinje cells with the basic dye (Fig. 10). This condition is rery similar to that described by Crile in the case of "a soldier who had suffered from hunger, thirst, and loss of sleep; had made the extraordinary forced march of 180 miles from Mons to the Marne; in the midst of that great battle was rounded by a shell; lay for hours waiting for help, and died from exhaustion soon after reaching the ambulance."

\section{Summary of Histological C'hanges.}

There is a generalized early chromatolytic change in the cells of the central nervous system. This change varies in intensity. The cells most affected are the small cells in which the basophil substance has partly or almost dis. appeared. In the larger cells the Nissl granules are smaller and not packed so closely together as normal. The small cells of the medulla and pons are slightly swollen, and the nucleus is large and clear. This change is present in some of the large cells, but it is less evident. This change indicates a relative degree of exhaustion of the kinetoplasm, assuming that the amount of the basophil substance is an index of biochemical neuropotential. The Nissl granules are not present in the neurone during life, but they disappear altogether in a cell that (prior to death of the whole body) has been so injured as to decay and die. Granted this premiss, then, it may be assumed that the cells of this man are in a state of commencing nerv. ous exhaustion, some nuclei of cells show the changes more markedly than others-for example, the cells of the vago-accessorius nucleus.

The vessels of the pia arachnoid membranes of the brain are congested, and thcre are scattered subpial haemor. rhages of microscopic size ahnost everywhere.

In the white matter of the corpus callosum, the internal capsule, the pons, and medulla there are seen congested reins and haemorrhage into the sheaths of these vessels; with occasionally extravasation of blood corpuscles into the adjacent tissues.

Case Ir.

Clinical Notes.

Captain Duffield reported that information obtained from the medical officer attached to the unit in which the man, a gunner in the Royal Garrison Artillery, was serving, was to the effect that he was sitting in a corrugated iron hit, fifty rards from some boxes of cordite cartridges, when a shell landed and exploded them. The man became unconscious at once; his breathing was stertorous; his boly showed no signs of wounds.

On the same day he was removed to a dressing station and thence to a casualty clearing station; in the evening of that day he died. The meilical officer there stated that the patient was absolutely unconscious, and could not be roused. His breathing was stertorous and slow; the pupils were equal and reacted to light; knee-jerks were difficult to obtain. He died shortly afterwards, and at the post-mortem examination the brain was removed, placed in spirit, and dispatched,
Macroscopical Appearance of Brain.

On the upper surface of the cerebellum; and upon the temporo-sphenoidal and left orbital lobes there was superficial haemorrhage. On cutting up the pons, oval patçlies of blood-stained tissue were seen as large as one-sixth by one-quarter inch; whether this is simple staining of haemorrhage cannot be determined until a microscopical examination has been made. Portions of the mesencephalon and pons were taken for microscopical examination; the medulla oblongata was not sent.

\section{Microscopical Examination.}

Post-parietal-Meninges: Marked congestion of all vessels of the surface of the brain with extravasation of blood into the soft membranes. In the grey matter of the cortex the perirascular spaces are dilated tlirough. out, and the vessels, capillaries, veins, and arteries are for the most part emptys In the white matter no punctate haemorrhages are seen; there is marked dilatation of the perivascular spaces; the capillaries, veins, and arteries are empty. In the cortex there is dilatation of the perineuronal spaces, which in many instances may be seen conmunicating. with the perivascular spaces (see Fig. 8).

Ascending Frontal.-Stained with thionin. The large pyramidal cells show pretty marked chromatolysis without swelling of cell : some of the Betz cells show commencing breaking up of the tigroid bodies; smaller pyramidal cells show undoubted swelling of nucleus and loss of pyramidal shape (very similar to that observed in experimental anaemia in animals) with varying degrees of chromatolysis. As a rule, the smaller the cell the more marked is the change (Fig. 9).

Orbital Lobe- - On the under surface there is extensive extravasation of blood into the substance of the brain and on the surface, and there is very marked dilatation of the perivascular spaces everywhere. The cortex is in a measure destroyed in one place; very marked dilatation of perineuronal as well as perivascular spaces, which intercommunicate.

Corpus C'allosum.-There is much congestion of ressels, and many have ruptured into the sheath, forming long, irregular branching, haemorrhagic extravasatious, but no sign of punctiform haemorrliage. Betz cells scem rather shrunken than swollen in the ascending frontal.

Temporal Lobe.-Shows remarkable dilatation of the perivascular spaces, and there is a big globular haemor. rhage, and much scattered haemorrhage into the substance of the brain.

\section{Opinions of Freich and German Authors. Regiadict}

"Shele Shock" By Windage.

Many discussions have taken place by French and German neurologists regarding the question of organic changes occurring in the central nerrous system as a resuit of vent du projectile, or windage. According to Léri, a true commotion appears only to be produced at a proximal distance of some ten metres from great pro. jectiles. The finding of groups of men dead in the last attitude of life, in closed spaces such as the German "pill boxes" and concrete dug-outs, and the proven fact that enormous forces of compression and decompression are generated by the detonation of high explosives in great shells, aërial torpedoes, and mines, has lent support to the view that mere proximity to the explosion is sufficient to cause organic changes in the brain and spinal cord by the compression and decompression of gases the result of the detonation of the explosive and of the atmospheric air: altogether apart from actual concussion caused by violent contact with solid materials, such as sandbags or the earth forming the walls of a dug-out, which may at the same time causc burial or partial burial, unattended by visible evidence of injury of the body sufficient to account for symptoms of cerebral or spinal concussion. The patient is rendered unconscions and his mind is a blank concerning what happened, in a true case of commotio cerebri; conse. quently he is unable to say whether he had or had not been concussed by the sand or earth. In the trro cases under consideration there was no history of burial.

Undotibtedly the rast majority of non-fatal cases of shell shock are more emotional in origin than com. motional, and occur especially in subjects of an inborn neurotic or neuropathic temperament; but the tiro conditions may be associated. Both Léri and Meige emphasize. 
the fact that commotional symptoms are not influenced by psychotherapy. They also point to the fact that in cases where organic changes have occurred the cerebro-spinal fluid withdrawn by lumbar puncture exhibits macroscopic or microscopic evidence of blood, indicating that baemorrhage had occurred.

In Case I Captain Stokes noted at the post-mortom examination that the fluid was blood-stained, and the microscopic findings of ruptured vessels explain this.

Léri states that the subjects of commotion are generally depressed, asthenic, aboulic, and often more or less confused mentally; they present almost constantly, even in light cases, pronounced disturbances of voltaic vertigo. They often suffer with bleeding from the ear, or nasal or vesical haemorrhage. Roussy and l'Hermitte admit that in rare cases "vent du projectile" may cause organic changes.

Robert Bing gives a review of the German opinions upon nervous accidents determined by the near explosion of a projectile. He points out that Vogt and Gaupp, who have occupied themselves with "Granat Kontusion" (bomb con. tusion), are far from accepting the exclusive psychogenic rôle in the development of this syndrome. Gaupp insists particularly upon the relations which exist between the initial symptoms presented by these patients and the rapid succession of atmo. spheric compression and decompression which takes place at the moment of the bursting of the pro. jectile. The existence of la b y $\mathrm{r}$ in thine lesions, almost regularly in this class of case, is in support of this opinion (Schultze and Meyer).

In Von Sarbo's numerous publications upon the subject there is a tendency to view these cases from a uniform point of view. For him the general mass of observations do not permit the diagnosis of organic changes in the usual sense of the word, nor that of psychoneurosis. He belieres micro-structural alterations occur, but which are not equivalent to the molecular changes of Charcot. He includes in the micro-structural changes meningeal oedema, microscopic haemorrhages, transitory paralysis of vessel walls, and contusion of nuclei and centres. In the initial period these lesions may give rise to some discrete symptoms of organic disease; later they are manifested by functional physical and psychical symptoms. Bing remarks that the pseudo-neurasthenia of arterio-sclerosis supports this view. It is interesting to note that the haemorrhages into the perivascular sheaths of ressels observed in Case I resemble in somie respects those seen in arterio-sclerosis.

Oppenleeim's view of traumatic neuroses had few supporters at the congress at Munich. Clarence Farrar sums up thas the work of a German psychiatrist:

"Aschaffenburg examined soldier's in Flanders who had been exposed to shell fire in the trenches but had escaped unwounded and were apparently well. The examinations took place in most cases within twenty-four hours after leaving the trenches. Of 74 men so examined, 67 showed unmistakable signs of localized organic lesions of the nervous system, although not as a rule of a serious natruc. A second examination a week later showed that some, but not all, of these phenomena had disappeared. Here were cases, therefore, in which an organic basis was present but no traumatic neuroses had developed. Aschaffenburg gives the result of his experience in these words:

"In assuming organic changes as one of the consequences of strell explosion I do not thereby agree with Oppenheim that the nervous symptoms are to be attributed to these changes. On the contrary it is to be noted that the most exagseraterl hystèrical cases which develop after exposure to shell firing are the ones which exhibit organic symptoms least of all.'

Hypotheses regarding the Lesions of "Commotion."

Two hypotheses have been put forward to explain organic lesions by "commotion":

1. Compression of the gas and atmosphere, so that the cranium and spine is struck, as it were, by a solid body and the vibration is transmitted through the bony struc. tures to the cerebro-spinal fluid and thence to the brain and spinal cord, causing a molecular disturbance of the delicate colloidal structures of the neurones, particularly those of the nuclei in the floor of the fourth ventricle, where the fluid is most abundant, and where it acts as a water cushion upon which the vital cardio-respiratory centres rest.

2. Compression is followed by a corresponding decompression, causing the liberation of bubbles of gas in the blood and tissues leading to embolism.

Probably both the forces of compression and decompres: sion act in producing vascular disturbances in the central nervous system, causing arterio-capillary anaemia and venous congestion.

Compentary.

In Case I, of which I have described the histo. logical changes, it may be observed that there was a condition of mania during life; this maniacal excitement may be correlated with the marked venous congestion of the cortex, the microscopic subpial haemorrhages, and a certain degree of scat. tered arterio-capillary collapse and emptiness. 'This, however, could not be held responsible for the suddenly fatal termination; the haemorrhage into the sheath of a fair-sized vessel (see Fig. 4) in the median raphe of the medulla and the generalized congestive venous stasis, with a condition of exhanstion of the cells of the vagoaccessorius nucleus (as shown by the almost complete disappearance of the Nissl granules (see Fig. 5) as compared with the cells of the adjacent hypoglossal nucleus), coupled with the condition of the heart found post mortem, may explain the sudden death.

The cerebral anaemia, as shown by collapsed and empty arterioles and capillaries with dilated perivascular and perineuronal spaces (see Figs. 7 and 8), is similar to the appearances in sections of brains of animals that have been killed within a few days after ligation of both carotid and vertebral arteries. The veins are congested similarly, but the capillary anaemia and chromatolytic changes would possibly explain many of the symptoms of sufferers with true shell shock-namely, headache, giddiness, amnesia (anterograde as well as retrograde), dizzy feelings, lack of power of attention, and fatigue-stupor, inertia, mental confusion, terrifying dreams-symptoms which are generally met with in recent cases.

There is, in both Cases I and II, a general, though as a rule not marked, chromatolytic change indicative of a lack of kinetoplasm in the neurones of variable degree. This may hypothetically, but with reason, be regarded as an expression of a fall in the general store of neuro-potential of the central nervous system. The cells of Purlkinje of the cerebellum show especially a complete or partial loss of the basophil substance.

'The vascular changes arc microscopic and widespread; there are no punctate haemorrhages of the white matter, such as I have described in gas poisoning, and which aro due to a lrvaline thrombosis of terminal arterioles. Tho 


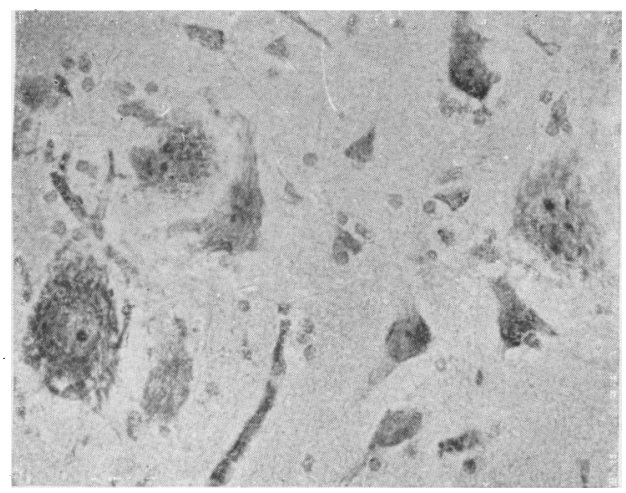

Fig. 1.

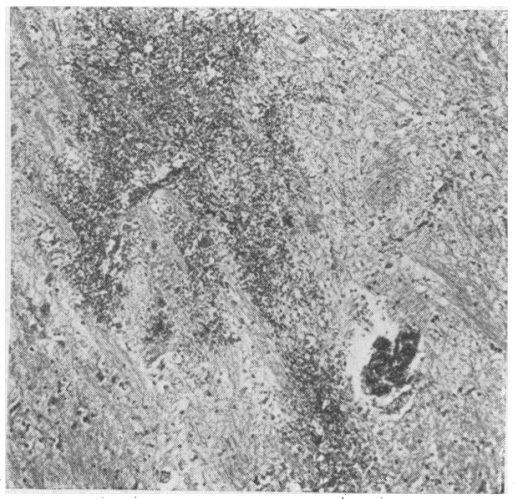

FIG. 3.

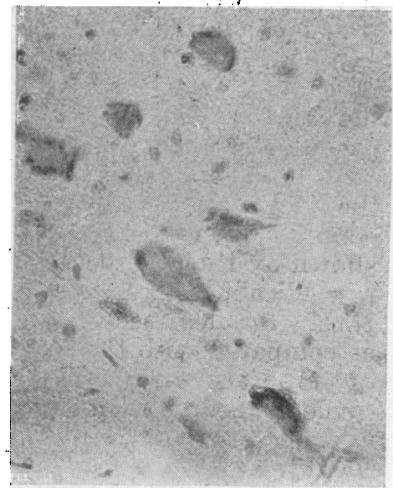

Fí. 5.

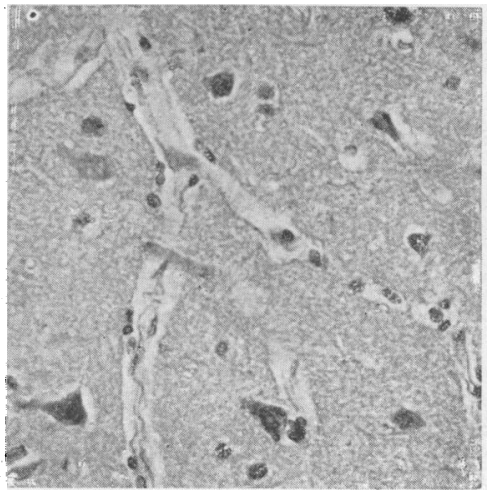

FIG. 8.

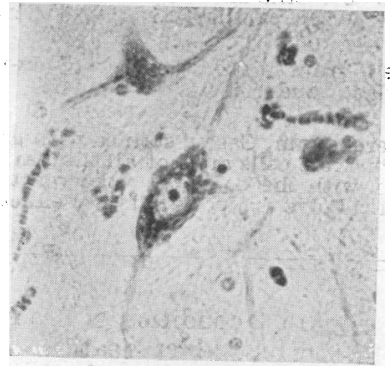

FIG. 6.

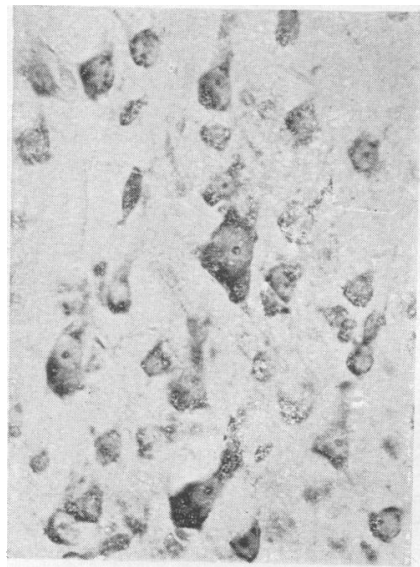

FIG. 9.

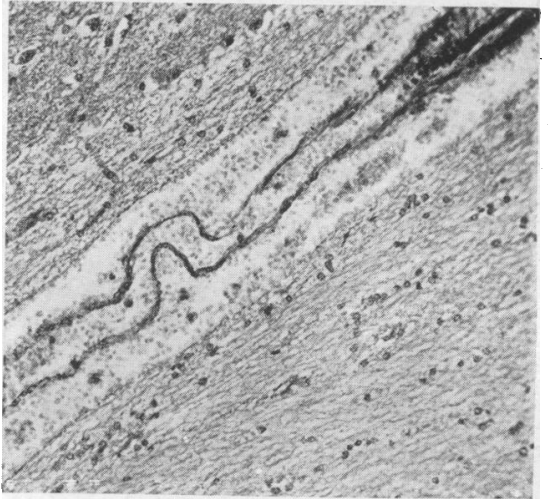

FI. 2.

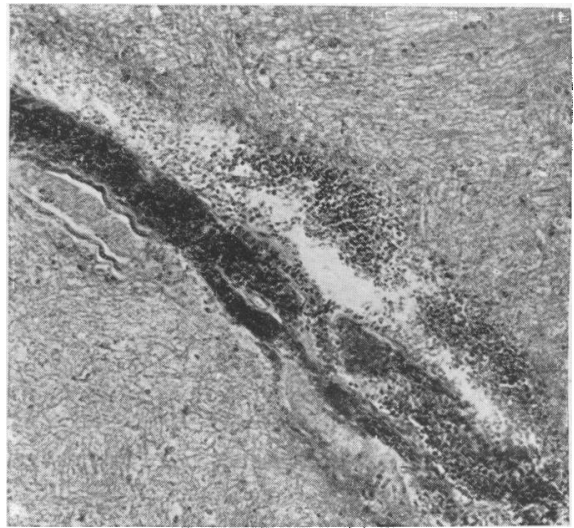

FIG. 4.

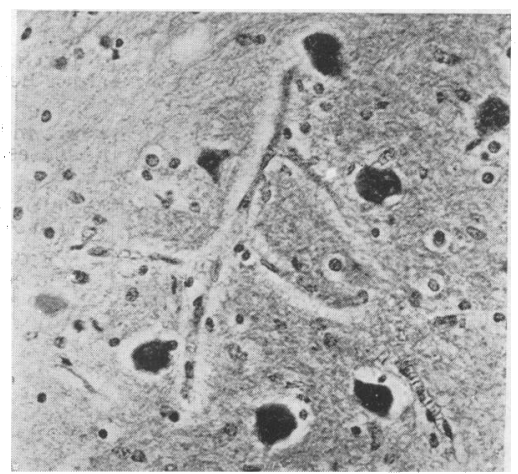

FIG. 7.

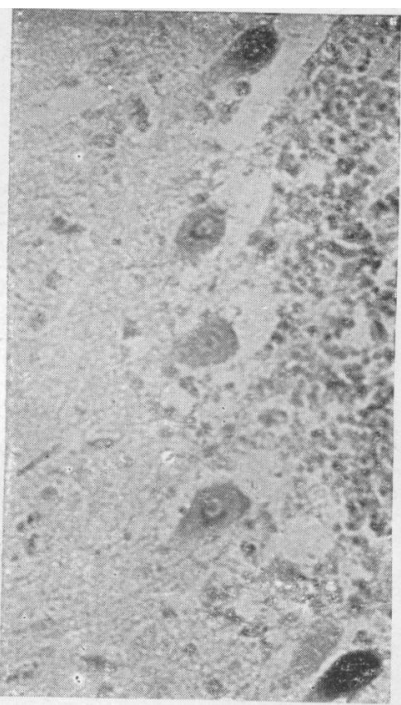

FIG. 10. 
CAPTAIN S. M. CONE: PATHOLOGICAL FINDINGS IN NERVES FOLLOWING WAR INJURIES.

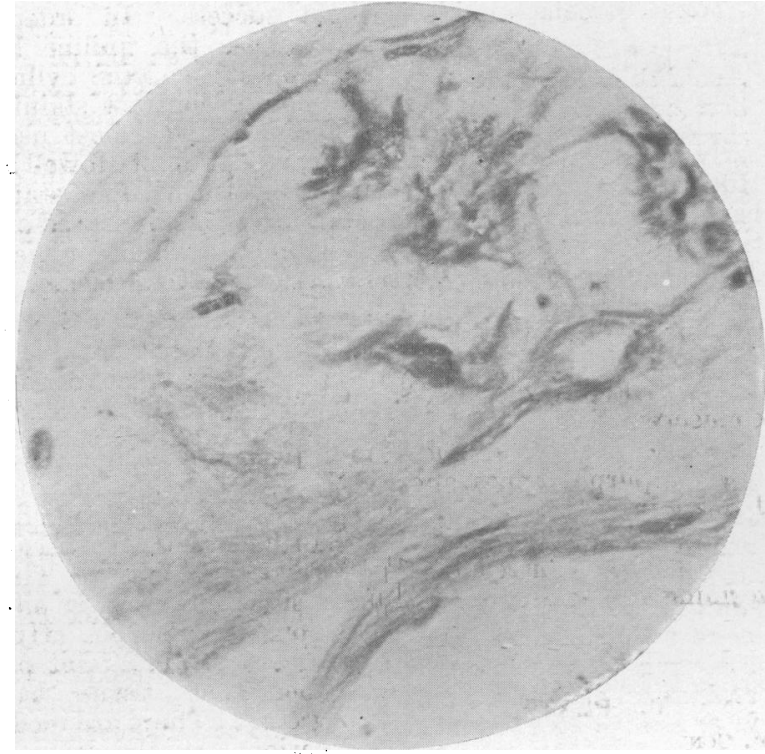

FIG. 1.

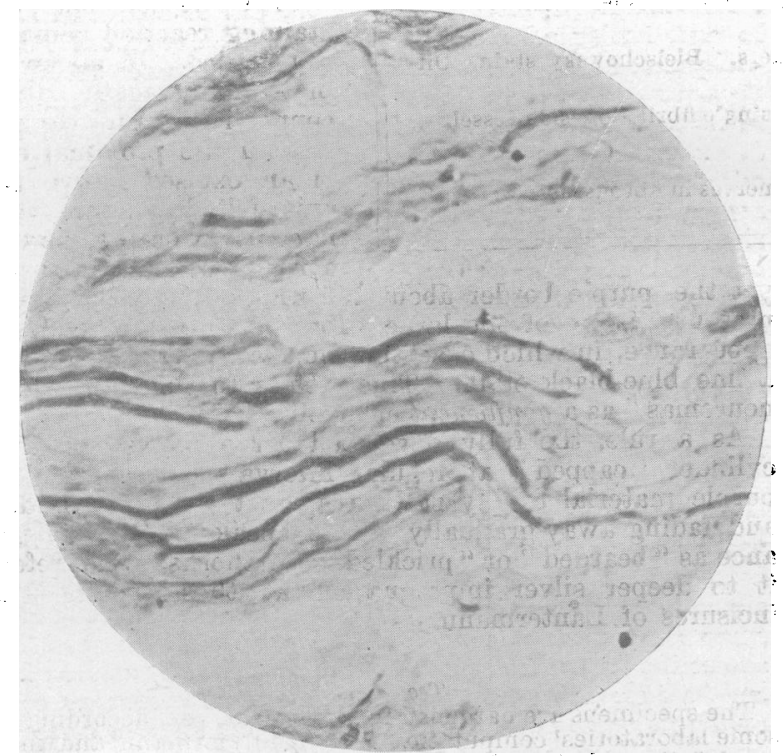

FIG. 3.

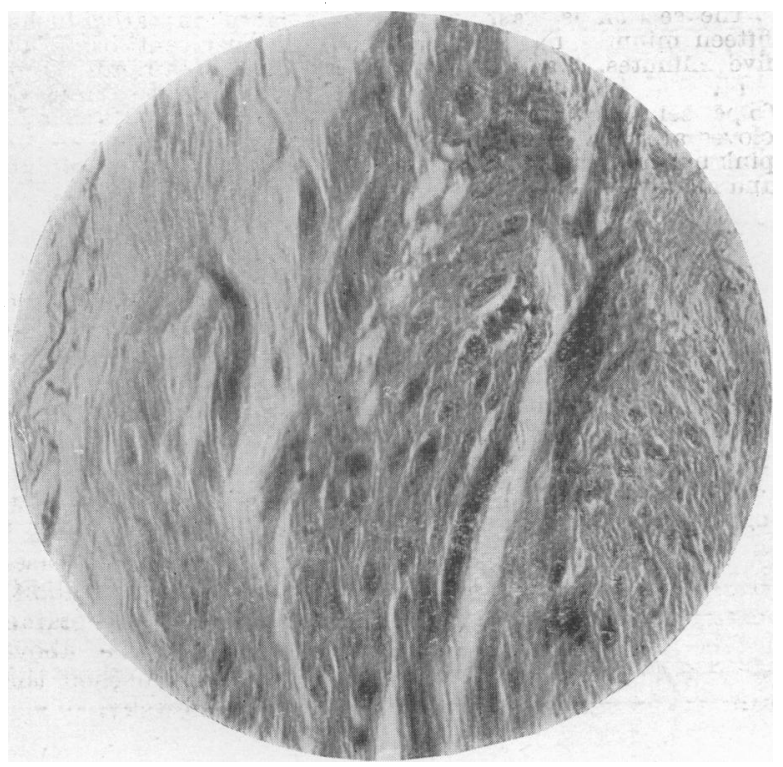

FIG. 5.

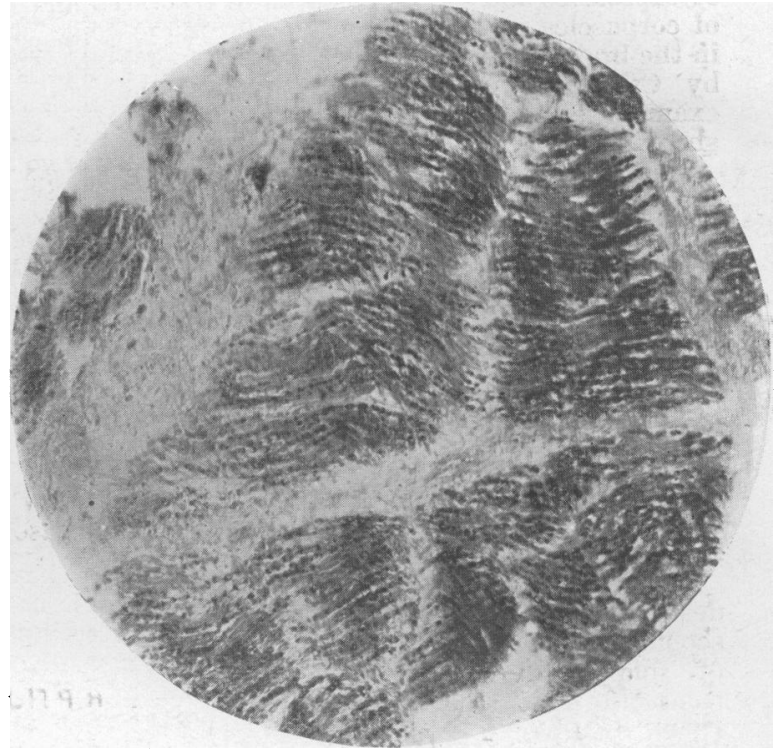

FIG. 2.

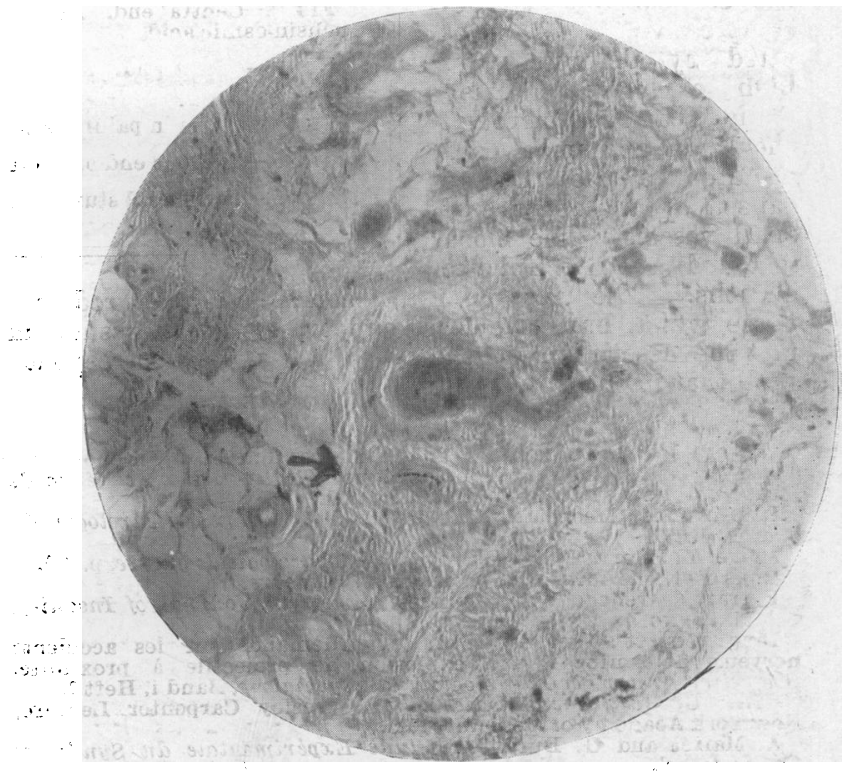

... _. Fig. 4.

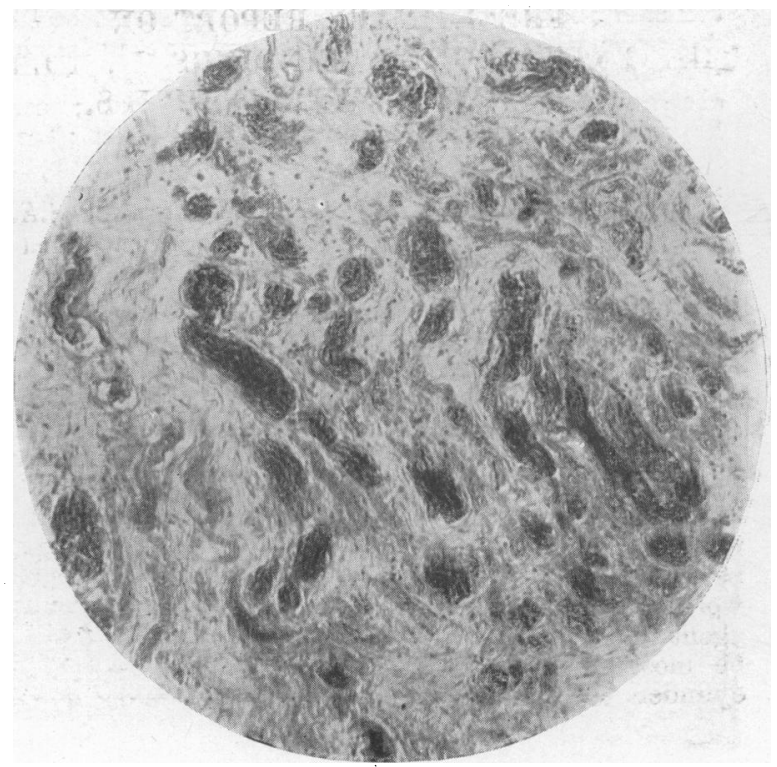

FIG. 6. 
haemorrhages are into the dilated perivascular sheaths (see Figs. 2 and 3). In the corpus callosum the networks of capillaries and small vessels show fractures and escape of corpuscles into the tissues. The microscopic changes in the brain confirm in every way the opinion expressed by Captain Stokes when he made the post-mortem examination that he was dealing with a case of shell shock.

In Case II the extensive haemorrhage on to the under surface of the orbital lobe withont visible external injury is of interest. : The force of the explosion must have been enormous: What happened to the man when it occurred we do not know.' The cortical, arterial and capillary ressels were empty, the perivascular sheaths weie in many places dilated and filled presumably with cerebrospinal fluid (see Fig. 9). The cortical neurones are swollen up, the nuclei are large and clear; the basophil substance is diminished in amount, a condition very like that observed in the cells of the cortex of an animal in which experiniental cerebral anaemia had been effected. Owing to the brief clinical and post-mortem notes this case is of inuch less interest than Case $\mathrm{I}$.

I am unable to find in tlee literature at my disposal any description of the micro. scopic changes in the brain of soldiers dying from commotio cerebri without risible external injüry.

Mairet and Durante have exposed animals to the compressive and decompressive forces gene. rated by detonation of high explosives. They found scattered through the brain and spinal cord minute haemorrhages caused by the rupture of small vessels. The blood is found in the lymphatic sheaths. The vessels most commonly ruptured are those which have the least support by solid tissue; in fact the description of their findings closely corresponds , vith that in the above cases,

\section{Bibliggraphr.}

- Lépine, Jean: La commotion des centres nerreux par explosion. Considération pathogénique et clinique. Bulletin de l'Académie de Códecin $t$. lxxvi No: 27,4 jnillet 1916,1

Iiéri, Andre, Médecin Chef: Levue neurologique, Neirotogie de querre, p. 757

Neige, i. Henry: Revue neurologique, Neurologie de guerre, p. 760

Roussy et l'Hermitte: Psychonécrose de guerve.

Farrar, Clarence: War Neuroses, American Journal of Insanity, rol. Ixxiii, No. 4 .

Bing. Robert: Revue, "Opinions Allemands sur les accidents nerreux determines par lexplosion de projectile it proximite. Schweizer Archiv fiur Neurologic und Psychiatrie, Band i. Heft 2 .

Crile, G. W.: The Kinetic Drive. Wesley Carpenter Lecturc New York Academy of.Medicine, 191

A. Mairet and G. Durante: Étude Expérimentale du Syndrome. Commotioncl.

\section{PRELIMINARY REPORT ON \\ THE PATHOLOGICAL FINDINGS IN NERVES} FOLLOWING WAR INJLRIES.

$$
\text { [With Special Plate.] }
$$

$\mathrm{BY}$

Captain SYDNEY M. CONE, M.O.R.C., U.S.A.

From the Alder Hey Military Orthopaedic Hospital, and tho ihompson-Yates Laboratory, Lni versity of Liverpool.)

THE incentive to the work I am doing on nerre pathology comes from Colonel Sir Robert Jones, who has placed the extensive material from the Alder Hey Military Ortho paedic Hospital in my hands. The Cniversity of Liverpool and Professor Ernest Glynn, Captain R.A.M.C.(T.), have given me every facility and aid in prosecuting nuy studies, and I am greatly indebted to them.

This is only a preliminary report of worls covering three months' service at the hospital, and is produced prinicipally beeause I feel I can give some material assistance to other workers along these lines by presenting the staining re. agent which, after three months' work, I finally found to be most satisfactory. Without a good stain for axis cylinder and medullary sheath one cannot do nerve work in the laboratory. Many of the stains require un. usual experience before they can be used satisfactorily. I tried Stroebe's stain without success. In order to make use of it Kenuedy had to use the aniline blue for twenty-four hours. Bielschowsky's axis cylinder stain required sereral days and did no contrast staining: maybe it had to be done over again. It was most useful early in my work, as was also a modification of Howell and Huber's picric acid haematoxylin method. The stain I have to give worker's in nerve pathology is one based on a technique I used in Heidelberg when working on nerve degeneration in Kïhne's laboratory in 1895. It brings our the axis cylinders in distinct relief as pink covered by a thin line of purple-black - the medullary sheath "neuro. keratin framework" faintly tinged purple-black-the red blood cells brown, the nuclei pink, muscle deep red, connective tissue unstained, or a very faint pink.

Where the axis cylinders are just formed they always have a purple appearance. Not infrequently fine liues 1 to $2 \mu$ in width are seen among the wider fibrils, the finer ones appearing deeper stained than the wider ones because of the pink centres of the fuller-grown fibres. 'These forming axis cylinders may be easily picked out in adhe. sions as purple lines against a very faint pink connective tissue back. ground. There are modifi. cations in the structure of the axis cylinder's and nerve fibres in denser con. nective tissue, but the staining reaction remains unmodified. In one speci. men of unusually dense connective tissue forma. tion in the proximal encl of an excised nerre the axis cylinders were very irregular, varicose, and of a rough outline by turns, yet the purple border about the pink central tendril was present. Some of the larger fibres showed a vacuolated appearance, in which case the vacuoles were outlined by a fine blue-black stain. Tinel refer's to this in "stump neuromas" as a gonflement of myelin.

As a rule, the fully developed nerve shows the axis

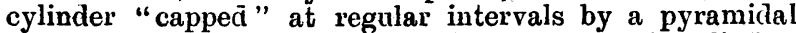
purple material cleeply stained against the axis cylinder, and fading away gradually. Tinel speaks of this appear. ance as " bearded " or "prickled with thorns," and refer's it to deeper silver impregnation at these points-the incisures of Lantermann.

Technique.

The specimens are hardened in 10 per cent. (or, according to some laboratories' computation, 4 per cent.) formalin and then carried through the alcohols to ether and absolute alcohol and celloidin. Althongh thin sections are preferable, good results are obtained with $20 \mu$ thick sections.

The section is washed in water, placed in carbol-fuchsin fifteen minutes, momentarily in water, 1 per cent. osmic acid five minutes, water two minutes, watery safranin 50 per cent. one minute, acid alcohol 1 per cent. two minutes, 95 per cent. alcohol five minutes. Absolute alcohol and oil of cloves are now used alternately until the section appears deep pink but trauslucent; it is then placed in xylol for two minutes and mounted in Canada balsam.

\section{Adrantages.}

The great value of seeing the nerve fibres distinctly out. lined against counective tissue, cell proliferation, and blood ressels will be appreciated at once by those who examine tissue from the great number of excised "nerve callus" masses of way stargery.

In our experience we havo had so far more than one liundred cases to examine. We have sectioned the excised nerves at proximal cnd, distal end, middle, and adlesions, ineluding muscle and fat. We have had old operations to go over in sorne of which Cargile'membrane, faseia virapping, or reins had been used. In one case a rabbit's nerve had been used as a graft. This material was stained in about trenty-five different ways before the abovedescribed method was adopted. The only method that approached satisfaction was that of Bielschowsly. 